\title{
Letter to the Editor: The Invasive Caribbean Mytilopsis sallei (Bivalvia: Dreissenidae): A Short Review
}

\author{
Dan Marelli, ${ }^{1, *}$ \\ ${ }^{1}$ Scientific Diving International, 1119 Clark Avenue, Tallahassee, FL 32301, USA \\ *Corresponding author: dmarelli@scientificdiving.com
}

SUBMITTED 23 April 2020

ACCEPTED 26 June 2020
ABSTRACT This letter seeks to comment on the taxonomy of members of the genus Mytilopsis (Bivalvia: Dreissenidae) that are found as invasive species in many Asian estuarine systems.

(c) The Author(s) 2020. This article is distributed under a Creative Commons Attribution-ShareAlike 4.0 International license.
A paper in volume 35(1-2) of the ASEAN Journal on Science E Technology for Development, authored by KS Tan and T Tay (Tan and Tay 2018), suggests that the dreissenid mussel Mytilopsis sallei (Récluz, 1849) is widely distributed in brackish waters of the Indo Pacific as a non-indigenous invasive species. That the species is invasive is not in question, what is in question is the identification of this mussel as M. sallei. The authors correctly state that there is some taxonomic confusion among species of Mytilopsis that has been going on for over 40 years. It is clear that a detailed study of the molecular and morphological characters of members of the genus needs to be conducted on recent members of the family Dreissenidae. However the authors incompletely summarize the members of the genus Mytilopsis and offhandedly then reject the opinions of several bivalve taxonomists, including myself, and suggest a synonymy of Mytilopsis sallei and M. adamsi Morrison, 1946. Specimens of Mytilopsis were collected from Fiji in the late 1800 s, decades prior to the opening of the Panama Canal. The holotype of Mytilopsis allyneana Hertlein and Hanna,
1949 (synonymized by me with M. adamsi) is in the collection of the California Academy of Sciences, CAS-IZ 65461 and was collected in Fiji by Andrew Garrett, a man who died in 1885 . The decision by Tan \& Tay and others to ignore the facts and opinions of other researchers in this matter seems arbitrary and unrooted in demonstrated, peerreviewed research. Yes the members of the genus Mytilopsis are difficult to separate on the basis of morphology and within species there is substantial variation in size, shape and coloration. I would be pleased to examine specimens from anywhere the authors choose and render an opinion, but until proven otherwise the species Mytilopsis adamsi is considered valid and is likely the animal that is found in many Indo-Pacific estuarine systems.

\section{REFERENCES}

Tan KS, Tay T. 2018. The invasive Caribbean Mytilopsis sallei (Bivalvia: Dreissenidae): a short review. ASEAN J Sci Technol Dev. 35(1-2):133-139. doi:10.29037/ajstd.483. 